\title{
De tre former for teoretisk viden
}

\author{
Pierre Bourdieu (1930-2003) \\ Professor i sociologi, Collège de France
}

Den sociale verden kan underkastes tre former for teoretisk viden, som hver især implicerer et sæt (oftest tavse) antropologiske teser. Det eneste disse tre former for viden har til fælles er, at de alle står i modsætning til praktisk viden. For det første: Fænomenologisk viden (eller, hvis man foretrækker at tale i termer fra tidens herskende skoler, "interaktionistisk" eller "etnometodologisk" viden) ekspliciterer primære erfaringer af den sociale verden; perception af den sociale verden som naturlig og indlysende er per definition ikke selvrefleksiv, og udelukker alle spørgsmål om dens egne mulighedsbetingelser. For det andet: Objektivistisk viden, (hvor den strukturalistiske hermeneutik konstituerer et specielt tilfælde) konstruerer de objektive relationer (f.eks. økonomiske eller lingvistiske), som strukturerer ikke kun praktikkerne men også repræsentationerne af praktikkerne og i særdeleshed primær praktisk og tavs viden om den kendte verden; objektivistisk viden konstruerer disse relationer ved hjælp af et brud.med den primære viden og således med de tavst antagne præsuppositioner, som giver den sociale verden dens indlysende og naturlige karakter. Objektivistisk viden kan kun begribe den sociale verdens objektive strukturer og den primære erfarings objektive sandhed (hvor eksplicit viden om disse strukturer er fraværende); den opstiller selve problemet, som doxisk erfaring om den sociale verden per definition udelukker, nemlig problemet med de (specifikke) betingelser under hvilke denne erfaring er mulig. For det tredje: Praxeologisk viden er ikke kun beskæftiget med systemet af de objektive relationer konstrueret af den objektivistiske form for viden, men også med de dialektiske relationer mellem disse objektive strukturer og de strukturerede dispositioner, som de producerer, og som modsat tenderer mod at reproducere de objektive strukturer; det vil sige den duale proces af internalisering af eksternalitet og eksternalisering af internalitet. Denne viden forudsætter et brud med den objektivistiske form for viden, dvs. den forudsætter unders $\varnothing$ gelser af mulighedsbetingelserne og følgelig unders $\varnothing$ gelser af grænserne for det objektivistiske synspunkt, som begriber praktikkerne udefra som en fait accompli, snarere end at konstruere deres generative princip ved at placere sig i deres fuldbyrdelsesproces.

Den praxeologiske form for viden kan forekomme at være en regression til den fænomenologiske form for viden, mens den implicerede kritik af objektivismen kan blive blandet sammen med kritikken af den videnskabelige objektivisering, som den formuleres af naiv humanisme i respekt for

Teksten er en oversættelse af Bourdieu (1973). Oversættelsen er tidligere publiceret i Callewaert et al. (red.) (1994/2008, s. 72-108). Antologien udkom i fem oplag: dels fra Akademisk Forlag (1994, 1995, 1997 og 1998), dels fra forlaget Frydenlund (2008). Oversætterne takker Frydenlund for tilladelsen til at bringe teksten her.

Publisert: 01.01.2019

Praxeologi - Et kritisk refleksivt blikk på sosiale praktikker (C2019 Pierre Bourdieu

DOI: http://dx.doi.org/10.15845/praxeologi.v1i0.1564 
den levede erfaring og i retten til subjektivitetens navn. Fordi den praxeologiske vidensform er et produkt af en dobbelt teoretisk bevægelse, som resulterer $\mathrm{i}$, at man endnu en gang vender om på det, man allerede har vendt om på. Den praxeologiske vidensform indebærer, at man vender om på den problematik, som den objektive videnskab om den sociale verden, set som et system af objektive relationer, har skabt. Omvendingen består i, at den objektive videnskab igen stiller alle de problemer på dagsordenen, som den praktiske erfaring og den fænomenologiske analyse af denne erfaring har udelukket fra dagsordenen. Ligesom objektivistisk viden opstiller problemet om mulighedsbetingelserne for den praktiske erfaring og derved demonstrerer, at den praktiske erfaring fundamentalt set er defineret ved det faktum, at den ikke opstiller mulighedsbetingelsens problem, bringer den praxeologiske viden den objektivistiske viden på ret køl igen ved at opstille de teoretiske, men også de sociale mulighedsbetingelser for objektiveringens problem og gør det på samme tid indlysende, at den objektivistiske viden er fundamentalt defineret af det faktum, at den udelukker dette problem. I modsætning til den praktiske opfattelse af den sociale verden er den objektivistiske viden fjernet fra opgaven med konstruktionen af teori om praktisk viden om den sociale verden. Praxeologisk viden udelukker ikke de fordele, der udgår fra den objektivistiske viden; den bevarer og overskrider dem snarere ved at integrere det, som denne viden blev nødt til at udelukke for at opnå dem.

Vi må et øjeblik opholde os ved det, som er objektivismens felt par excellence, semiologien. Ligesom Ferdinand de Saussure postulerer, at sproget er et autonomt objekt, irreducibelt til dets konkrete aktualiseringer, dvs. til den tale-adfærd, som det muliggør, så etablerer Erwin Panofsky det han med Alois Riehl kalder Kunstwollen; med andre ord, groft sagt kan den objektive betydning af et arbejde ${ }^{1}$ lige så lidt reduceres til kunstnerens "vilje" som til "tidsalderens vilje" eller til den levede erfaring, som arbejdet vækker i beskueren. Ved at gøre sådan, gennemfører både Saussure og Panofsky - med hensyn til tale som en specifik form for adfærd og i forbindelse med kunstværker som specifikke handlingsprodukter - de operationer, som opbygger den objektivistiske videnskab ved at opbygge et system af objektive relationer. De objektive relationer er præcis lige så irreducible til praktikkerne, gennem hvilke de er virkeliggjorte og manifesterede, som de er irreducible til subjekternes intention og til en hvilken som helst viden subjekterne må have om de objektive relationers tvang og logik. Saussure viser, at kommunikationens sande medium mellem to agenter ikke er talen som en umiddelbar kendsgerning, fastholdt i sin observerbare materialitet, men sproget som den struktur af objektive relationer, der muliggør både produktionen og afkodningen af tale. Tilsvarende viser Panofsky, at den ikonologiske fortolkning behandler et kunstværks empiriske egenskaber med de affektive erfaringer, de måtte give ophav til, og som blotte "kulturelle symptomer", der kun til fulde giver mening gennem en aflæsning bevæbnet med den kulturelle kode, som skaberen selv har "involveret" i sit arbejde.

Umiddelbar "forståelse" forudsætter en ubevidst afkodningsoperation, der kun kan være fuldstændig adækvat, når den kompetence, som en af agenterne involverer i sin praktik eller i sine arbejder, er identisk med den kompetence, som den anden agent objektivt involverer i sin perception af den førstes praktik eller arbejde; med andre ord, i det specielle tilfælde, hvor kodningen - forstået som transformationen af en subjektiv betydning til en praktik eller et arbejde falder sammen med den symmetriske afkodningsoperation. Umiddelbar "forståelse", en afkodningshandling, der ikke anerkender sig selv som sådan, er kun mulig (og kun fuldt opnået) i det specielle tilfælde, hvor den historiske kode, som muligg $\varnothing$ r den (ubevidste) afkodningshandling, er fuldstændigt mestret (som en kultiveret disposition) af den perciperende agent og falder sammen

\footnotetext{
1 "Det, som 'præsenterer sig selv', ikke for os, men objektivt som den ultimative og definitive mening af det
} kunstneriske fænomen" (Panofsky, 1920, s. 321-339). 
med den kode, der (som en kultiveret disposition) har muliggjort frembringelsen af den perciperede praktik eller arbejde. Delvis eller total misforståelse er reglen i alle andre tilfælde; illusionen om umiddelbar forståelse leder til illusorisk forståelse, der stammer fra etnocentrismen, forstået som en kodeinterferens; for at sige det kort, når det eneste kognitive værktøj er det, Edmund Husserl benævnte den "intentionelle overførsel ind i den Anden", er selv den mest 'forstående' oversættelse kun en særlig form for etnocentrisme, som man ikke kan blive forarget over.

Som arvingen til en intellektuel arv, den lingvistiske, hvis frembringelsesbetingelser de ikke altid er i stand til at reproducere, har strukturalistiske antropologer alt for ofte stillet sig tilfreds med en bogstavelig oversættelse af de lingvistiske termer, fjernet fra den struktur hvorfra de udleder deres oprindelige betydning. Herved sparede de sig selv for besværet med at foretage deres egen epistemologiske refleksion over betingelserne og grænserne for validiteten af transponeringen af Saussures konstruktion. Det er for eksempel bemærkelsesværdigt, at med undtagelse af Edward Sapir, der i kraft af sin dobbelte dannelse som lingvist og antropolog var prædisponeret til at rejse problemet om forholdet mellem kultur og sprog, har ingen antropolog fors $\emptyset$ gt at fremdrage alle implikationerne af homologien mellem to modsætninger, sprog og tale på den ene side og adfærd og arbejde på den anden side (hvilket Leslie White virkelig formulerer eksplicit som den eneste). Objektivismen fastslår, at umiddelbar kommunikation er mulig, hvis og kun hvis agenterne er objektivt disponerede på en sådan måde, at de associerer den samme betydning med det samme tegn (tale, praktik eller arbejde) og det samme tegn med den samme betydning. Eller for at sige det på en anden måde: Hvis de i deres kodnings- og afkodningsprocesser, f.eks. i deres praktikker og deres fortolkninger, begge refererer til et og samme system af konstante relationer, uafhængigt af individuel bevidsthed eller vilje og irreducibel til deres forekomst i form af praktikker eller produkter af arbejde (kode eller ciffer). Ved at gøre dette afviser objektivismen ikke den fænomenologiske analyse af primær erfaring af den sociale verden og af den umiddelbare forståelse af tale eller handling: Objektivismen sætter blot grænserne for den primære erfarings validitet ved at etablere de specielle betingelser, inden for hvilke den primære erfaring er mulig, og som den fænomenologiske analyse lader ude af betragtning. De sociale videnskaber har, nødvendigvis, ifølge Husserl "en tematik med en konsistent dobbelt orientering, en tematik der konsistent sammenkæder teorien i det videnskabelige felt med en teori om viden om denne teori" (Husserl, 1965, s. 52); med andre ord: Epistemologisk refleksion over de antropologiske videnskabers mulighedsbetingelser udgør en integreret del af de antropologiske videnskaber. Dette er for det første tilfældet, fordi en videnskab, der som sit objekt har selve det, der gør videnskaben mulig, såsom sprog eller kultur, kun kan konstituere sig ved konstitueringen af dens egne mulighedsbetingelser; men for det andet fordi komplet viden om videnskabens betingelser, det vil sige om de operationer, hvorved videnskab opnår symbolsk mestring af et sprog, en myte eller et ritual, implicerer viden om praktisk forståelse: Den praktiske viden udfører de samme operationer, selvom dette sker i absolut uvidenhed om de generelle og specielle betingelser, hvorunder det er muligt, og som giver den praktiske sans sit særpræg.

Det er tilstrækkeligt at unders $\varnothing$ ge de teoretiske handlinger, ved hjælp af hvilke Saussure opbygger lingvistik som en videnskab ved at behandle sproget som et autonomt objekt adskilt fra dets materialisation i tale, for at afsløre de forudantagelser, der er implicitte i en hvilken som helst form for viden, som behandler praktikker eller arbejder som symbolske fakta til dekodning, og mere generelt behandler dem som fuldbyrdede fakta snarere end praktikker. Selvom man kunne påberåbe sig eksistensen af $d \varnothing$ de sprog eller stumhed $\mathrm{i}$ alderdommen for at demonstrere, at det er muligt for tale at forsvinde, mens sproget bevares, og selvom sprogfejl afslører sproget som konstituerende for de objektive normer bag talen (hvis det var anderledes, ville enhver sprogfejl modificere sproget, og der ville dermed ikke eksistere sprogfejl), forekommer tale at være betingelsen for sprog, såvel fra et individuelt som fra et koilektivt synspunkt. Det forholder sig sådan, fordi sprog ikke kan begribes 
uden tale, fordi sproget læres ved hjælp af tale og fordi tale ligger bag oprindelsen til innovationer i og transformationer af sprog. Men rækkefølgen af de to nævnte processer er blot kronologisk; når man forlader feltet af den individuelle eller den kollektive historie for at stille spørgsmål til de logiske betingelser for afkodning, som den objektivistiske hermeneutik gør det, vendes forholdet på hovedet: Sproget er betingelsen for talens forståelighed, det vil sige den formidling, som i forsikringen om associationernes identitet til lyde og koncepter udført af afsendere og modtagere garanterer fælles forståelse. Så fra dette synspunkt, forståelighedens, er tale et produkt af sproget (Saussure, 1960, s. 37-38). Heraf følger, at fordi det er udviklet fra et strengt intellektualistisk synspunkt, det afkodende, giver Saussures lingvistik tegnenes struktur, det vil sige forholdene mellem dem, forrang, på bekostning af deres praktiske funktioner, der aldrig er reducerbare til funktionen af kommunikation eller viden, hvilket strukturalismen tavst antager: Disse praktikker - som tilsyneladende på det strikteste er rettet mod funktionen af kommunikationen for kommunikationens skyld (den fatiske funktion) eller kommunikationen med viden som formålet, såsom fester og ceremonier, rituelle udvekslinger eller, i et helt andet felt, cirkulationen af videnskabelig information - er altid mere eller mindre åbenlyst orienteret mod politiske eller $\emptyset$ konomiske funktioner.

Strukturalistiske lingvister baserer konstruktionen af en meddelelses strukturelle egenskaber som sådan, det vil sige som system, på formodningen om en upersonlig og udskiftelig afsender og modtager og på ignoreringen af de funktionelle egenskaber, som enhver meddelelse skylder sin anvendelse inden for en særlig socialt struktureret interaktion. Faktisk ved vi allesammen udmærket, at de symbolske interaktioner inden for en gruppe ikke kun afhænger af de symbolske strukturer inden for den gruppe, hvori de forekommer (Moscovici \& Plon, 1966, s. 701-722), men også af de sociale strukturer, hvori de interagerende agenter er situeret (for eksempel klassestrukturerne): Som konsekvens heraf er det sandsynligt, at en undersøgelse af de symbolske udvekslinger - som ifølge Eliot D. Chapple og Carleton S. Coon (Chapple \& Coon, 1947, s. 283) ville gøre os i stand til at skelne mellem den første gruppe, der udelukkende responderer, og den anden gruppe, som responderer på afsendelser fra den første gruppe - ville åbenbare, hvor afhængig den symbolske magtstrukturs relationer er af den politiske magtstrukturs relationer, såvel på samfundets niveau i sin helhed som inden for en vilkårlig gruppe. Den fuldkomne konkurrencemodel er lige så urealistisk her som ethvert andet sted, idet markedet for symbolske goder også har sine monopoler og sine dominansstrukturer.

Kort sagt, det øjeblik man skifter fra strukturen af et sprog til de funktioner, det opfylder, det vil sige til den brug, agenterne virkelig gør af det, ser man, at viden udelukkende om koden kun tillader en meget ufuldstændig mestring af de lingvistiske interaktioner, som faktisk foregår; som Luis Prieto observerer, afhænger betydningen af et lingvistisk element i det mindste lige så meget af ekstralingvistiske som af lingvistiske faktorer, ergo af konteksten og af situationen, hvor de forekommer. Det er som om modtageren, i klassen af de betydningsbærere, som abstrakt korresponderer med Iyden af tale, "valgte" den, der forekom ham passende til omstændighederne, sådan som han opfattede dem (Prieto, 1966, s. 334-358). Sagt på en anden måde betyder det, at modtagelsen (og uden tvivl også afsendelsen) stort set afhænger af de objektive strukturer i relationerne mellem de objektive positioner i de interagerende agenters sociale struktur (f.eks. konkurrencerelationer, objektivt antagonistiske relationer eller magt- og autoritetsforhold etc.), for det er denne struktur, som determinerer formen, antaget af de interaktioner, der kan observeres inden for en bestemt sammenhæng.

Intet demonstrerer bedre utilstrækkeligheden af den teori om praktik, som hjemsøger lingvistisk (og også antropologisk) strukturalisme, end dens manglende evne til i denne teori at integrere alt det, der ligger i udførelsen, som Saussure siger det. Grunden til denne mangel ligger i den manglende 
evne til at tænke på tale og, mere generelt, på praktik som andet end udførelse. ${ }^{2}$ Objektivismen konstruerer en teori om praktik (som udførelse), men kun som et negativt sub-produkt eller, kunne man sige, som affaldsprodukt, umiddelbart kasseret, efterladt fra konstruktionen af sprog eller kultur som systemer af objektive relationer. Så med det formål inden for sproglige fakta at afgrænse "sprogfeltet" og at isolere "et veldefineret objekt", "med en homogen struktur", "et objekt, det er muligt at studere separat" afviser Saussure det "fysiske aspekt ved kommunikationen", det vil sige tale som et forkonstrueret objekt, der er tilbøjelig til at forhindre konstruktionen af sproget; siden isolerer han, inden for "tale-kredsløbet", det han betegner som "udførelses-aspektet", det vil sige tale som et konstrueret objekt, defineret som aktualiseringen af en bestemt betydning af en bestemt kombination af lyde. Han eliminerer til slut muligheden af en bestemt betydning ved at fastslå, at "udførelsen aldrig udføres af kollektivet", men "altid er individuel". Således inddeles det samme begreb, talens, ved teoretisk konstruktion i en kendsgerning før konstruktionen, som er umiddelbart observerbar og netop det, som den teoretiske konstruktion udføres imod, og et konstrueret objekt, det negative produkt af den handling, hvorved sproget som sådan konstitueres, eller bedre, som producerer de to objekter ved at producere de modstridende forhold, inden for hvilke og ved hjælp af hvilke de defineres. Det ville være let at vise, at konstruktionen af kultur-begrebet - $i$ kulturantropologiens forståelse - eller af det sociale strukturbegreb (i Alfred R. Radcliffe-Browns betydning og en social-antropologisk forståelse) også implicerer konstruktionen af et opførselsbegreb som udførelse, som sameksisterer med det primære opførselsbegreb, som simpel adfærd, der tages for pålydende. Den ekstreme forvirring af debatterne om forholdet mellem 'kultur' (eller 'sociale strukturer') og opførsel stammer almindeligvis fra det faktum, at den konstruerede opførselsbetydning og den implicerede praktik-teori fører en skjult eksistens inden for diskursen både hos tilhængerne og modstanderne af kultur-antropologi. Faktisk kan de mest virulente modstandere af begrebet 'kultur', såsom Radcliffe-Brown, kun fremkomme med en naiv realisme imod ideernes realisme, som gør "kultur" til en transcendent og autonom realitet, der udelukkende adlyder sine egne interne love. ${ }^{3}$ Den implicitte status af denne praktik-teori er det, der beskytter objektivismen

2 "Heller ikke den psykologiske del af kredsløbet er fuldstændigt ansvarlig: Den udøvende del mangler, for udførelsen foretages aldrig af et kollektiv. Udførelsen er altid individuel, og individet er altid mesteren: Jeg vil kalde den udførende del talende (parole)" (de Saussure, 1959, s. 13). Den mest eksplicitte formulering af teorien om tale som udførelse findes helt bestemt i Louis Hjelmslevs arbejder, som klart afslører de forskellige dimensioner i den saussurianske modsætning mellem sprog og tale, hvor det første er institutionelt, socialt og "rigidt" og det andet er udførelse, individuelt og "ikke-rigidt" (Hjelmslev, 1959, især s. 79).

3 "Lad os overveje, hvad de konkrete observerbare fakta, som antropologen beskæftiger sig med, er. Hvis vi går i gang med at studere, f.eks. de aboriginale indbyggere i en del af Australien, finder vi et bestemt antal individuelle mennesker $i$ et bestemt naturligt miljø. Vi kan observere disse individers adfærds-handlinger, inklusive selvfølgelig deres tale-handlinger og de materielle produkter af forgangne handlinger. Vi observerer ikke en 'kultur', fordi dette ord betegner ikke en konkret realitet, men en abstraktion, og som det almindeligvis bruges, en vag abstraktion. Men direkte observation vil ikke afsløre for os, at disse mennesker er forbundet ved et komplekst netværk af sociale relationer. Jeg bruger termen 'social struktur' til at betegne dette netværk af faktisk eksisterende relationer" (Radcliffe-Brown, 1940, s. 1-12). Årsagen til den ekstreme forvirring, der omgiver debatten om ideen om kultur ligger formodentlig i det faktum, at de fleste forfattere placerer - om det så kun er for at modstille dem - begreber af meget forskellig epistemologisk status, såsom kultur og samfund eller individet eller opførsel etc. på samme niveau. Den imaginære dialog om ideen om kultur, som præsenteres af Clyde Kluckhohn og William H. Kelly (se Kelly \& Kluckhohn, 1945), giver et mere summarisk, men samtidig mere livligt billede af denne debat end det, der kan findes i Kluckhohn \& Kroeber (1952). Edmund R. Leach har observeret, at på trods af deres tilsyneladende modsætning, er Bronislaw K Malinowski og Radcliffe-Brown i det mindste enige om at opfatte hvert 'samfund' eller hver 'kultur' (med deres respektive ordforråd) som en "totalitet bestående af et antal af adskilte, empiriske 'ting' af meget forskellig art - f.eks. 
mod den eneste virkelig afgørende kritik, som ville være rettet mod objektivismens praktik-teori, ophav til alle de metafysiske vildfarelser vedrørende "kulturens locus", vedrørende "strukturen"s eksistensform eller vedrørende systemernes histories ubevidste finalitet, for ikke at nævne den alt for berømte "kollektive bevidsthed". ${ }^{4}$

I mangel af konstruktions-praksis udover den negative, dvs. som udførelse, er objektivismen dømt til enten kun at registrere regelmæssigheder, mens den ignorerer hele spørgsmålet om deres produktions-principper, eller at tingsliggøre abstraktionerne ved at behandle objekter konstrueret af videnskaben - hvad enten det er "kultur", "strukturer", "sociale klasser", "produktionsmåder", etc. som autonome realiteter, udstyret med sociale egenskaber og i stand til at handle som subjekter ansvarlige for historiske handlinger eller som en kraft i stand til at sætte grænser for praktikker. Selv om den har fortjeneste af at afvise de rå former for ideernes realisme, tendererer hypotesen om det ubevidste ikke desto mindre mod at maskere de modsætninger, der opstår ud fra usikkerhederne $\mathrm{i}$ forbindelse med den praktik-teori, som "strukturel antropologi" accepterer, om det så kun er ved fors $\varnothing$ mmelse. Og endnu værre tillader den restaureringen - i den tilsyneladende sekulariserede form af en struktur, som struktureres uden hjælp fra nogen strukturerende principper - af den klassiske metafysiks finalårsager. Medmindre, selvfølgelig, man med Émile Durkheim antager, at ingen af de implicitte regler, der begrænser subjekterne, "kan findes i deres fuldkommenhed i individernes anvendelse, fordi de kan eksistere, også selvom de ikke bliver anvendt" (Durkheim, 1956, s. 11), og som en konsekvens heraf antager, at reglerne besidder den transcendente og permanente eksistens, som Durkheim tilskriver alle kollektive "realiteter", er det umuligt at undslippe den mest rå naivitet, legalismen. Legalismen, som tror, at praktikkerne er produktet af at adlyde normer, kan man kun undslippe ved at spille på den mangesidede betydning af ordet regel: Regelbegrebet bliver oftest benyttet i betydningen social norm, udtrykkeligt fastslået og eksplicit anerkendt, som i moralen eller ved en juridisk lov eller af og til i betydningen en teoretisk model, en konstruktion udviklet af videnskaben for at forklare praktikker; ordet bruges også ekstraordinært i betydningen skema (schéme) (eller et princip), som er immanent i praktikken, som skal anskues implicit snarere end ubevidst, blot for at tilkendegive at den eksisterer, på en praktisk måde, i agenternes praktikker og ikke i deres bevidsthed.

Man behøver kun at genlæse det følgende afsnit fra forordet til andenudgaven af Structures elementaires de la parente ${ }^{5}$ (Elementære strukturer i slægtskab), som beskæftiger sig med adskillelsen mellem "foretrukne" og "foreskrivende systemer", i hvilken man må formode, at termerne norm, regel eller model anvendes særligt omhyggeligt:

grupper af mennesker, 'institutioner', 'sædvaner"' - eller som "et empirisk hele bestående af et begrænset antallet identificerbare dele". Sammenligningen af forskellige samfund har til formål at undersøge, hvorvidt de "samme slags dele" kan findes i ethvert tilfælde (Leach, 1961, s. 6).

${ }^{4} \mathrm{Hvis}$ vi udelader de sjældne forfattere, som tildeler begrebet opførsel en betydning som er strengt defineret ved de handlinger der konstituerer den, i modsætning til "kultur" (f.eks. H. D. Laswell, som fastslår: "If an act conforms to culture, then it is conduct, if not, it is behaviour", (Laswell, 1935). Uden at drage nogen konklusioner heraf, vil de fleste af dem, der opererer med denne modsætning, foreslå epistemologisk uoverensstemmende definitioner af kultur eller af opførsel, idet de modstiller et konstrueret objekt til en før konstrueret kendsgerning, lader de pladsen til det andet konstruerede objekt, nemlig praktikken, i betydningen udøvelsen, åben: Således - og det er langt fra det værste eksempel - modstiller Marvin Harris "kulturelle mønstre" til "kulturelt mønstrede adfærd", som "det, der er konstrueret af antropologerne" og "det, som medlemmer af et samfund holder sig til eller påtvinger andre" (Harris, 1951).

${ }^{5}$ Oversat til engelsk til: Levi-Strauss, C. (1969): The elementary structures of kinship. Social science paperbacks, London. 
I modsætning hertil kan et system, der rekommanderer ægteskab med morbroderens datter, kaldes foreskrivende, også selvom reglen sjældent observeres, eftersom det, den siger, skal gøres. Spørgsmålet om, hvorvidt og i hvilket omfang medlemmer af et givent samfund respekterer normen, er meget interessant, men et andet spørgsmål end, hvor dette samfund retteligen skal placeres i en typologi. For at kunne genkende det, vi kunne kalde en matrilateral operator, som arbejder i dette samfund og fungerer som pilot, er det tilstrækkeligt at erkende sandsynligheden for at opmærksomhed på reglen påvirker valgene, selvom det kun er ganske lidt i den foreskrevne retning, og at procentandelen af konventionelle, ægteskaber er højere end det ville være tilfældet, hvis ægteskaber blev indgået tilfældigt: Det vil sige, bestemte alliancer følger den vej, der udstikkes for dem, og dette er tilstrækkeligt til at kunne afbilde en specifik kurve over det genealogiske rum. Der ville uden tvivl være ikke kun én kurve, men et stort antal lokale kurver, imidlertid for en stor del dog kun ansatser, og disse ville kun i sjældne og exceptionelle tilfælde udgøre lukkede cyklusser. Men de strukturelle hovedlinjer, som fremkommer her og der, vil være nok til at systemet kunne bruges til at lave mere rigide systemer dog i en probabilistisk udgave, hvor ideen er fuldstændig teoretisk, og ægteskab ville tilpasse sig stramt til en hvilken som helst regel, den sociale gruppe ville vælge at formulere. (Levi-Strauss, 1969, s. 33, mine fremhævelser, P.B.)

Dette afsnit, som faktisk er hele forordet, er skrevet med henblik på normer, mens bogen Structural Anthropology (Levi-Strauss, 1968) er skrevet ud fra modeller, eller hvis man foretrækker det, ud fra strukturer; det senere ordvalg er ikke helt fraværende her, fordi systemet af matematiskfysiske metaforer, på hvilken den centrale passage baserer sig ("operator", "visse alliancer"; "følger den bane som er kortlagt for dem", "kurver" inden for det "genealogiske rum", "strukturer"), påkalder sig den teoretiske models logik og den - både målrettede og afviste - ækvivalens mellem model og norm:

Et præferentielt system er foreskrivende, når det anskues på model-niveau, et foreskrivende system skal være præferentielt når det anskues på realitets-niveau (Levi-Strauss, 1969).

Men for dem, der husker passagerne i Structural Anthropology om forholdet mellem sprog og slægtsskab (f.eks. "'slægtsskabs-systemer', som 'fonemiske systemer' opbygges af intellektet på den ubevidste tankes niveau" (Levi-Strauss, 1968, s. 34)) og den befalede bestemthed, hvormed de "kulturelle normer", alle "rationaliseringerne" eller de "sekundære argumenter" produceret af de indfødte, bliver tilbagevist til fordel for "ubevidste strukturer"; og ikke mindst for dem, der husker de passager, hvor universaliteten af den regel, der ligger til grund for exogami, bliver bekræftet, for dem kommer indrømmelser, som her gøres til "opmærksomhed på reglen" og afstandtagen fra disse rigide systemer, hvis idé er fuldkommen teoretisk, muligvis som en overraskelse. Det samme kan gælde dette afsnit fra forordet:

Det er ikke desto mindre sandt, at den empiriske virkelighed af de såkaldte foreskrivende systemer kun kan tages i sin fulde mening, når de relateres til en teoretisk model udarbejdet af de indfødte selv, før etnologerne kom til (Levi-Strauss, 1969, s. 32).

eller igen:

De der praktiserer dem, er fuldt ud klar over, at ånden i sådanne systemer ikke kan reduceres til den tautologiske proposition, at enhver gruppe modtager sine kvinder fra 'givere' og giver sine døtre til 'tagere'. De er også opmærksomme på, at ægteskab med den matrilaterale krydskusine (morbrors datter) udgør den simpleste illustration af reglen, den form, som har størst sandsynlighed for at garantere sin overlevelse. På den anden side ville et ægteskab med den patrilaterale krydskusine (fasters datter) uigenkaldeligt krænke denne regel. (Levi-Strauss, 1969) 
Man må her bemærke et afsnit, hvor Ludwig J. J. Wittgenstein opregner alle de spørgsmål, som er undgået den strukturelle antropologi og uden tvivl, mere generelt, hele intellektualismen, der transformerer den objektive sandhed, etableret af videnskaben, til en praktik, som udelukker den disposition, som $g \varnothing r$ det muligt at etablere denne sandhed: ${ }^{6}$

Hvad skal jeg kalde de regler, som han går frem efter? De hypoteser, som tilfredsstillende beskriver hans brug af ord; eller den regel, som han slår op, når han bruger tegn; eller den han giver os som svar, hvis vi spørger ham, hvilken regel han følger? Men hvis observation ikke gør os i stand til at se nogen klar regel, og hvis spørgsmålet ikke bringer nogen frem i lyset? For han gav mig faktisk en definition, da jeg spurgte ham, hvad han mente med ' $N$ '; men han var parat til at trække den tilbage og ændre den. Så, hvordan kan jeg afgøre, efter hvilke regler han spiller? Han ved det ikke selv. Eller for at stille et bedre spørgsmål: Hvilken betydning formodes udtrykket 'den regel, efter hvilken han handler' her at have lagt bag sig? (Wittgenstein, 1963, s. 38-39)

Det er at gå fra modellen af realiteten til modellens realitet at overveje regelmæssigheder, f.eks. hvad der gentager sig med en vis, statistisk målelig frekvens som produktet af en bevidst fastlagt og bevidst respekteret regulering (for således at kunne forklare både deres tilblivelse og deres effektivitet), eller som produktet af den ubevidste regulering af en eller anden mystisk cerebral og social mekanisme:

Tag eksemplet med forskellen mellem' toget er regelmæssigt to minutter forsinket' og 'I reglen er toget to minutter forsinket': ... i det sidste tilfælde antydes det, at det faktum, at toget er to minutter forsinket er et resultat af en politik eller en plan ... Regler relaterer sig til planer eller politikker, mens regelmæssigheder ikke gør det ... At fastslå, at der burde være regler i naturligt sprog, svarer til at kræve, at veje burde være røde, fordi dette ville korrespondere med de røde linjer på et kort. (Ziff, 1960, s. 38)

Alle sociologiske udsagn burde have et tegn foran sig, der annoncerer, at "det er som om", og fungerer ligesom kvantorer i logik, hvilket hele tiden ville minde os om den objektive videnskabs konstruerede begrebers epistemologiske status. Alting konspirerer om at opmuntre til en tingsligg ørelse af begreber, begyndende med ordinært sprogs logik, som er tilbøjelig til at drage den slutning, at substantivet medfører substansen, eller at tilkende begrebet evnen til at handle $\mathrm{i}$ historien på samme måde som de ord der betegner begrebet, er subjekt i sætningerne i den historiske diskurs. Som Wittgenstein har bemærket det, man skal kun glide fra adverbiet "ubevidst'" ("ubevidst har jeg tandpine") til substantivet det "ubevidste", eller til en særlig brug af adjektivet "ubevidst" (som i "jeg har en ubevidst tandpine") for at frembringe uhyrligheder af metafysisk dybde (Wittgenstein, 1965, s. 57-58). På samme måde kan man observere de teoretiske (og politiske) effekter, som er i stand til at blive frembragt af personifikationen af kollektiver (i sætninger som "bourgeoisiet mener, at ... " eller "arbejderklassen afviser, at ... "), hvilket vil være ensbetydende med at påstå eksistensen af en gruppe eller klasses "kollektive bevidsthed": Ved at tildele grupper eller institutioner dispositioner, som kun kan opstå i den enkeltes bevidsthed, selvom de er produktet af kollektive betingelser som for eksempel vækkelsen af bevidstheden om klasseinteresser, slipper man for at analysere disse betingelser og især de, som bestemmer graden af den overvejede gruppes objektive og subjektive homogenitet og graden af bevidsthed blandt dens medlemmer.

Den fejlslutning, der ligger bag legalisme, består implicit i de individuelle agenters bevidstheder, $\mathrm{i}$ at placere den teoretiske viden, som kun kan konstrueres og erobres imod praktisk erfaring; med andre ord består det af tildelingen af den antropologiske beskrivelses værdi til en teoretisk model,

\footnotetext{
${ }^{6}$ Ifølge Merleau-Ponty (1949, især s. 124 og 135). Dette er en overførsel uden grund af den samme type, som den, der genererer de intellektualistiske og empiricistiske fejl i psykologien.
} 
der er konstrueret for at gøre rede for praktikker. Teorien om handling som simpel udførelse af en model (i den duale mening af norm og videnskabelig konstruktion) er kun et af mange eksempler på den imaginære antropologi fostret af objektivismen, når man, som Karl Marx siger det, tager "logikkens ting for tingenes logik". Den ændrer praktikkernes eller værkernes objektive mening til producenterne af disse praktikker eller kunstværkers subjektive formål med aktiviteten. Dette fører til den umulige homo economicus, som underkaster sin beslutningstagen rationel kalkulation, lader sine spillere udføre roller eller handle i konformitet med modeller og sine talere vælge mellem fonemer.

\section{Strukturer, habitus og praktikker}

Det er $n \varnothing$ dvendigt at overskride metodisk objektivisme, idet det konstituerer en $n \varnothing$ dvendig fase inden for al forskning, som et redskab, der letter bruddet med den primære erfaring, og som et instrument til konstruktionen af objektive relationer. For at komme væk fra strukturens realisme, der behandler systemer af objektive relationer som substanser ved at omdanne dem til heler, der allerede er konstitueret uden for individets historie og gruppens historie, er det både nødvendigt og tilstrækkeligt at gå fra opus operatum (det fuldbyrdede værk) til modus operandi (måden at gå til værks), fra statistisk regelmæssighed eller fra algebraisk struktur til princippet om produktionen af denne observerede orden: Konstruktionen af praktik-teorien, eller mere præcist af måden, hvorpå praktikker genereres, er betingelsen for konstruktionen af en eksperimentel videnskab om internalitetens og eksternalitetens dialektik, dvs. om internaliseringen af eksternaliteten og om eksternaliseringen af internaliteten. Strukturerne ved en speciel type miljø (f.eks. de materielle eksistensbetingelser karakteristiske for en klasse), som kan begribes empirisk i form af de regelmæssigheder, der er forbundet med et socialt struktureret miljø, producerer habitus, systemer af varige dispositioner, ${ }^{7}$ strukturerede strukturer prædisponerede til at fungere som strukturerende strukturer, dvs. som principperne for genereringen og struktureringen af praktikker og repræsentationer. Som en konsekvens heraf kan miljøets strukturer være objektivt "regulerede" og "regelmæssige" uden på nogen måde at være produktet af lydighed mod love; de er objektivt tilpasset deres formål, uden at forudsætte nogen bevidst målrettethed og explicit bemestring af de handlinger, der leder til disse mål. I og med dette, er de kollektivt orkestreret uden at være produktet af en dirigents orkestrerende handlinger.

Selv når de ser ud til at være bestemt af fremtiden, dvs. af de eksplicitte - og eksplicit udtrykte formål med et projekt eller en plan, er praktikkerne produceret af habitus, som det genererende princip af strategier, der gør én i stand til at klare uforudsete og evigt skiftende situationer, og er determineret af den implicitte foregribelse af situationernes konsekvenser; ved at være determineret af de foregående betingelser for produktionen af princippet for deres produktion, tenderer de altid mod at reproducere de objektive strukturer, som de, i den sidste analyse, er produktet af. Således er det eksempelvis i interaktionen mellem to agenter eller grupper af agenter $\mathrm{i}$ besiddelse af den samme habitus (kaldet A og B), som om handlingerne fra hver af dem (kaldet a1 for A) er organiseret på en sådan måde i relation til de reaktioner, de ville fremkalde hos enhver agent, som er $\mathrm{i}$ besiddelse af den samme habitus (kaldet b1, B's reaktion på a1), at de objektivt foregriber den reaktion, som disse reaktioner i deres tur fremkalder (kaldet a2, reaktionen på b1). Intet kunne dog

\footnotetext{
${ }^{7}$ Ordet "disposition" synes at være særlig kongruent med habitus-begrebet (defineret som et system af dispositioner): For det første udtrykker det resultatet af en organiserende handling, som har en betydning meget tæt på ord som struktur; ydermere betegner det en væremåde, en habituel status (i særdeleshed vedrørende kroppen) og især en prædisposilion, en tendens, en hang, eller en tilbøjelighed.
} 
være mere naivt end at acceptere den teleologiske beskrivelse, ifølge hvilken enhver handling (f.eks. al) ville være designet for at muliggøre reaktionen på den reaktion, den fremprovokerede (f.eks. a2 som reaktion på b1). Habitus genererer en sekvens af "træk", som er objektivt organiserede som strategier uden på nogen måde at være produktet af en sand strategisk intention (hvilket eksempelvis ville forudsætte, at de skulle opfattes som én strategi blandt mange mulige strategier).

Vi kan ikke udelukke den mulighed, at den respons som habitus giver, vil være en strategisk kalkulation, der quasi-bevidst tenderer mod at udføre, hvad habitus udfører på en anden måde, nemlig et skøn over chancerne baseret på transformeringen af den fuldbyrdede effekt til en forudset fremtidig effekt. Disse responser er ikke desto mindre primært relateret til et felt af objektive potentialiteter umiddelbart indeholdt i nutiden - ting der skal gøres eller ikke skal gøres, der skal siges eller ikke siges - hvilket i modsætning til fremtiden som "absolut mulighed" (absolute Möglichkeit) i Georg W. F. Hegels forstand, projiceret af det rene projekt af en "negativ frihed", har en påtrængende nødvendighed og et krav på en eksistens, der udelukker enhver overvejelse. Symbolske stimuli, dvs. konventionelle og konditionelle stimuli, som kun indvirker på agenter, der er $\mathrm{i}$ stand til at opfatte dem, tenderer mod at påtvinge sig selv, ubetinget og nødvendigvis, når indprentningen af det vilkårlige ophæver det vilkårlige i selve indprentningen og af de indprentede betydninger: Verden af fremtrædelser, af allerede opnåede mål; af objekter i besiddelse af, som Husserl siger det, en "permanent teleologisk karakter", som for eksempel redskaber; af allerede afmærkede stier; af værdier transformeret til ting, som er praktikkens verden, kan kun tillade en konditionel frihed - liberet si liceret - snarere lig friheden hos den magnetiske nål, der som Gottfried $W$. Leibniz forestillede sig det, faktisk $n \varnothing d$ at pege mod nord. Man kan regelmæssigt observere et meget nært slægtskab mellem videnskabeligt konstruerede objektive sandsynligheder (f.eks. mulighederne for adgang til højere uddannelse eller til museer etc.) og subjektive forhåbninger ("motivationer"): Dette er ikke sådan, fordi agenterne bevidst justerer deres forhåbninger efter en nøje vurdering af deres chancer for succes - som når en spiller kan modificere sine væddemål som en funktion af fuldstændig information vedrørende gevinstchancerne - som vi implicit antager når vi, idet vi glemmer, at "det ser ud som om", handler som om spilteorien eller sandsynlighedsberegningen, der begge er konstrueret imod spontane dispositioner, svarer til antropologiske beskrivelser af praktik. Idet man fuldstændigt vender objektivismens tendens om, kan vi i reglerne for den videnskabelige konstruktion af sandsynligheder eller strategier modsat søge, ikke en antropologisk praktikmodel, men snarere en negativ beskrivelse af de spontane strategiers implicitte tendenser, eller af de statistikker, som de nødvendigvis implicerer, fordi de eksplicit er konstrueret imod disse implicitte tendenser (f.eks. tilbøjeligheden til at tillægge primære erfaringer en overdreven betydning). Ulig den videnskabelige sandsynlighedsberegning, der er baseret på kontrollerede eksperimenter og på data etableret efter præcise regler, bringer den subjektive evaluering af en specifik handlings chance for succes $i$ en specifik situation et helt korps af semiformaliseret viden og regler på banen: Visdom, ordsprog, almenviden, etiske forskrifter ("det er ikke noget for os") og, mere dybtliggende, de ubevidste principper for et etos, der er en generel og overførbar disposition, der som et produkt af læring domineret af en specifik type af objektive regelmæssigheder, determinerer 'rimelig' eller 'urimelig' opførsel for enhver agent, der ligger under for disse regelmæssigheder. ${ }^{8}$ "Aldrig så snart bliver vi bekendt med umuligheden af at tilfredsstille et

\footnotetext{
8 "Vi kalder denne subjektive, variable sandsynlighed - som af og til udelukker tvivl og fremmer sikkerhed sui generis, og som til andre tider ikke fremtræder som andet end et vagt glimmer - for filosofisk sandsynlighed, fordi den refererer til de $\varnothing$ velser af højere orden, ved hvilke vi forstår tingenes orden og rationalitet. Alle fornuftige mænd har et forvirret begreb om lignende sandsynligheder; dette bestemmer derfor, eller i det mindste retfærdiggør, den urokkelige tro på det, vi kalder sund fornuft" (Cournot, 1922, s. 70).
} 
$\emptyset$ nske", sagde David Hume omtrent i sin Treatise an human nature (Hume, 1968), "førend ønsket selv forsvinder". Og Marx i Grundrids:

Ligemeget hvad jeg er, hvis jeg ikke har nogen penge til at rejse for, har jeg intet behov-forstået som et sandt behov for at rejse - der kan tilfredsstilles. Ligemeget hvad jeg er, hvis jeg føler en trang til at studere, men ikke har nogen penge til at betale for mine studier, har jeg ingen trang til at studere, dvs. ingen effektiv, sand trang. (Marx, 1974-78)

Praktikker kan være objektivt tilpasset til objektive muligheder, uden at agenterne behøver at udføre den mindste kalkulation, eller endnu mindre et mere eller mindre bevidst sk $\varnothing n$ over chancerne for succes: Så det er som om den a posteriori eller ex post sandsynlighed for en hændelse, som vi kender som resultatet af tidligere erfaring, vil determinere den a priori eller ex ante sandsynlighed, der subjektivt tilskrives den. Fordi de dispositioner, der vedvarende indprentes af de objektive betingelser (som videnskaben opfatter som sandsynligheder gennem statistiske regelmæssigheder, objektivt forbundet med en gruppe eller en klasse), giver anledning til forhåbninger og til praktikker, som er objektivt forenelige med disse objektive betingelser, og i nogen grad forud tilpasset til deres objektive krav, så bliver de mest usandsynlige udfald udelukket som utænkelige, enten uden overhovedet at blive unders $\varnothing$ gt eller på bekostning af en dobbelt negation, idet de i kærlighed til det uafvendelige tenderer mod at gøre en dyd af $n \varnothing d v e n d i g h e d e n$ ved afvisning af det, som alligevel ikke fås. Selve betingelserne for produktionen af et etos, at gøre en $d y d$ af nødvendigheden, er af en sådan art, at de forudsigelser, der kommer fra den, tenderer mod at ignorere de begrænsninger, som validiteten af enhver sandsynlighedsberegning ligger under for, nemlig at betingelserne for eksperimentet ikke skulle have været modificeret. Ulig videnskabelige skøn, som korrigeres efter hvert eksperiment i overensstemmelse med strenge regler, tilskriver praktiske skøn en uforholdsmæssigt stor vægt til primære eksperimenter: De karakteristiske strukturer for en bestemt type af eksistensbetingelser påvirker det relativt autonome univers af familieforhold ved hjælp af de $\emptyset$ konomiske og sociale $n \emptyset$ dvendigheder, eller bedre, producerer den habitus-struktur, der i sin tur genererer perceptionen og værdisættelsen af al videre erfaring gennem formidlingen af de specifikt familiale manifestationer af denne eksterne nødvendighed (f.eks. tabuer, bekymringer, morallektioner, konflikter, smag etc.). Endelig, på grund af effekten af det efterslæb, der altid følger i halen på logikken om habitus' genese, er praktikkerne altid udsat for negative sanktioner, og således til en "sekundær negativ styrkelse", når det miljø, som de faktisk konfronteres med, adskiller sig for meget fra det miljø, som de er objektivt tilpasset. Inden for den samme logik er det forståeligt, at generationskonflikter ikke er konflikter mellem aldersklasser adskilt på grund af egenskaber, som er naturlige for en vis alder, men er konflikter mellem forskellige klasser af habitus produceret ifølge forskellige genereringsmåder: Ved opstilling af forskellige definitioner på, hvad der er umuligt, muligt, sandsynligt og sikkert, får eksistensbetingelserne en gruppe til at erfare de samme praktikker eller forhåbninger som naturlige eller rimelige, som en anden gruppe finder utænkelige eller skandaløse, og vice versa.

Med andre ord må man opgive alle de teorier, der eksplicit eller implicit behandler praktik som en mekanisk reaktion, og som direkte er determineret af forudgående betingelser og fuldstændigt reducerbart til forud etablerede mekanismers virkemåde, "modeller", "normer" eller "regler"; hvis ikke, er man tvunget til at antage, at disse mekanismer eksisterer i uendelige antal som tilfældige konfigurationer af stimuli i stand til at udløse dem udefra, for således at være dømt til det samme grandiose og desperate arbejde, som en antropolog udførte, idet han bevæbnet med fint positivistisk 
mod iagttog 480 elementære adfærdsenheder i løbet af tyve minutter med sin kone i køkkenet. ${ }^{9}$ Men afvisningen af mekanistiske teorier implicerer på ingen måde, at vi ifølge den traditionelle modsætning mellem objektivisme og subjektivisme overlader den vilkårlige magt til en fri og kreativ vilje til straks at producere situationens mening ved at projicere de mål, der peger frem mod dens transformation. Det betyder heller ikke, at vi reducerer de menneskelige handlingers og værkers objektive intentioner og konstituerede betydninger til de bevidste og overvejede intentioner hos deres ophavsmænd. Praktik er på en og samme tid nødvendig og relativt autonom med reference til situationen i dens præcise umiddelbarhed, fordi den er produktet af det dialektiske forhold mellem en situation og en habitus, forstået som et system af varige og overførbare dispositioner, der integrerer alle forudgående erfaringer, og fungerer som en opfattelses-, vurderings- og handlingsmatrix, der muliggør opfyldelsen af en uendelig variation af opgaver. Takket være analoge overføringer af skemaer, praktiske metaforer i den strengeste betydning af termen, som tillader, at løsningen af problemer har den samme form, og takket være uophørlige korrektioner af de opnåede resultater, som disse resultater dialektisk producerer, er løsningen af en uendelig variation af opgaver mulig. Som det vedvarende princip for genereringen af regulerede improvisationer (principum importans ordinem ad actum som skolastikerne siger), producerer habitus praktikker, der tenderer mod at reproducere regelmæssighederne indlejret i de objektive betingelser for produktionen af deres genererende princip, mens de tilpasses til kravene indlejret som objektive potentialer i den direkte konfronterede situation. Derfor følger det, at praktikkerne hverken kan udledes direkte fra de objektive betingelser, defineret som den øjeblikkelige sum af de stimuli, der måtte synes direkte at have sat dem i gang, eller direkte fra de betingelser, som producerede det varige princip for deres produktion. Følgelig kan vi kun forklare disse praktikker, hvis vi relaterer den objektive struktur, der definerer de sociale betingelser for produktionen af den habitus, der skabte dem, til betingelserne for denne habitus' operation, dvs. hvis vi relaterer det forrige til dette sammentræf, der, undtagen når disse betingelser er blevet radikalt forandrede, repræsenterer en særlig tilstand af denne struktur. Habitus er i stand til at fungere som en operator, der i praksis opnår denne relatering af disse to systemer af relationer i og ved produktionen af praktikker, fordi den er historie omdannet til natur, dvs. fornægtet som sådan, fordi den ændres til en anden natur; det "ubevidste" er aldrig andet end forglemmelsen af historien, som historien selv producerer ved at inkorporere de objektive strukturer i form af disse quasi-naturer, habitus er:

Inden i enhver af os, i varierende proportioner, eksisterer der en del af gårsdagens menneske; det er gårsdagens menneske, der uundgåeligt prædominerer i os, fordi nutiden betyder så lidt $i$ sammenligning med den lange fortid, i hvilken vi blev formet, og af hvilken vi følger. Men vi opfatter ikke dette menneske fra fortiden, fordi det er så meget en del af os; det er den ubevidste del af os selv. Følgelig regner vi ikke mere med det, end vi regner med dets legitime krav. Tværtimod er vi meget opmærksomme på de mest nutidige krav fra civilisationen, fordi de, i og med at de er nutidige, ikke har nået at fæstne sig i vores ubevidste. (Durkheim, 1938, s. 16)

Hukommelsestabet vedrørende genesen, en af historiens paradoksale effekter, er også opmuntret af den objektivistiske perception (hvis ikke direkte forårsaget af den): For at forstå historiens produkt

\footnotetext{
9 "Her konfronteres vi med det pinefulde faktum, at analysen af det repræsentative udsnit af episoder er en del af et større segment af adfærd, som i den komplette registrering indeholder omtrent 480 separate episoder. Ydermere tog disse 480 adfærdsstrøms-hændelser kun 20 minutter. Hvis min kones adfærdsrate er nogenlunde repræsentativ for andre aktører, må vi være forberedt på at operere med en fortegnelse over frembragte episoder i st $\varnothing$ rrelsordenen 20.000 per 16-timers dag [ ... ] I en population der består af flere hundrede aktørtyper, må antallet af forskellige episoder i den totale fortegnelse nå op på mange millioner gennem et års cyklus" (Harris, 1964, s. 74-75).
} 
som et opus operatum og placere det forud for et fait accompli, er objektivismen nødt til at påkalde sig den præ-etablerede harmonis mysterier eller den bevidste aftales vidundere for at kunne gøre rede for det, der opfattet helt synkront fremstår som den objektive mening, hvad enten det er den interne sammenhæng af værker eller af institutioner, såsom myter, riter eller love, eller det er den objektive overensstemmelse, der er såvel manifesteret som forudsat i de overensstemmende eller ovenikøbet modstridende praktikker (for så vidt som de implicerer fælles repertoirer) hos medlemmerne af den samme gruppe eller klasse. Vildfarelsen i objektivismen er konsekvensen af den fuldstændige mangel på at analysere den duale internaliserings- og eksternaliserings-proces, eller mere præcist, produktionen af den objektivt overensstemmende habitus, som derfor er passende og tilbøjelig til at producere praktikker og værker, der selv er objektivt overensstemmende.

Fordi eksistens-betingelsernes identitet tenderer mod at producere (i det mindste delvist) ens systemer af dispositioner, genererer den resulterende habitus's (relative) homogenitet en objektiv harmonisering af praktikker og værker, idet den tilføjer dem den regelmæssighed såvel som objektivitet, som definerer deres specifikke 'rationalitet' og som resulterer i at de erfares som indlysende eller givne: De ses som umiddelbart forståelige og forudsigelige af alle de agenter, der besidder en praktisk mestring af det system af handlings- og tolkningsskemaer, som objektivt rummes i fuldbyrdelsen af dem og kun af disse; dvs. de er forståelige for dem, der ligesom medlemmerne af den samme gruppe eller klasse er produkter af identiske objektive betingelser, som udfører en universaliserende og partikulariserende effekt, for så vidt som de kun gør medlemmerne af en gruppe ensartede ved at udskille dem fra alle de andre. Så længe vi ignorerer det sande princip i denne dirigentløse orkestrering, som tilfører gruppens eller klassens praktikker regelmæssighed, enhed og systematik, og det i fraværet af enhver spontan eller påtvungen organisering af individuelle projekter, dømmer vi os selv til den naive artificialisme, som ikke anerkender nogen forenende principper i en gruppes eller klasses ordinære eller ekstraordinære aktiviteter udover den bevidste og formidlede overensstemmelse, der findes i sammensværgelser. På denne måde vil nogen uden andet bevis end deres egne fashionable indtryk benægte enheden af den herskende klasse og udfordre dem, som har det modsatte standpunkt til at etablere et empirisk bevis for, at medlemmerne af den herskende klasse har en eksplicit politik, udtrykkeligt påtvunget i eksplicit overensstemmelse. ${ }^{10}$ Andre, der i det mindste tilbyder en eksplicit og systematisk formulering af denne naive repræsentation af kollektiv handling, overfører det arketypiske spørgsmål om bevidsthedens filosofi til gruppe-niveauet, og ændrer opkomsten af klassebevidstheden til en slags revolutionært cogito,

10 "Hvad angår den margin af autonomi, som opleves af politisk personale med hensyn til industriel lederskab, er det hverken fastsat en gang for alle i ethvert givent land eller i forskellige aktivitetsdomæner. Jeg opfordrer Meynaud til at gøre rede for omskiftelserne i den franske dekoloniseringsproces med henblik på den indflydelse, der er udøvet af kapitalister (nogle var kolonialister, andre antikolonialister). Og jeg er sikker på, at han vil være ude af stand til at forklare general de Gaulles diplomati ud fra indflydelsen fra M. Villiers eller fra den franske arbejdsgiverforening" (Aron, 1965, s. 24). Fra hans lange "demonstration" af den herskende klasses ubevidsthed og manglende sammenhæng skal vi kun citere nogle få passager: "En af mine skuffelser har været at observere, at de, der ifølge den marxistiske repræsentation af verden bestemmer handlingernes kurs, for det meste ikke har nogle politiske ideer [...] Jeg har mødt et antal af denne 'fordømte race', jeg har aldrig oplevet, at de fastholdt resolutte eller enstemmige holdninger vedrørende den politik, der skulle følges [...] kapitalisterne selv var splittede. Blandt 'monopolister' eller 'store kapitalister' har jeg opdaget usikkerhed, tvivl og skænderier, som blev luftet offentligt i pressen og i parlamentet. For at kunne forestille sig, at det er dem, der har bestemt fransk politik, ville jeg være tvunget til at antage, at nogen blandt dem skulle være i stand til at påtvinge deres politikker [...] I de fleste af tilfældene har jeg kunnet observere direkte, at repræsentanterne for den store kapitalisme er mindre politisk motiverede, end det generelt antages" (Aron, 1965, s. 145-149). 
hvor dette alene menes at kunne sikre klassens eksistens ved at konstituere den som en "klasse for sig selv" ("Classe pour soi"). ${ }^{11}$

Den objektive harmonisering af gruppe- eller klasse-habitus resulterer i det faktum, at praktikker kan blive objektivt harmonerende uden nogen direkte interaktion og, a fortiori, i fraværet af nogen eksplicit overensstemmelse. "Forestil Dem", foreslog Leibniz, "to ure i perfekt overensstemmelse, hvad tiden angår. Dette kan opstå på tre måder. Den første består af gensidig indflydelse; den anden i tildelingen til hver en dygtig arbejder, som korrigerer og synkroniserer dem kontinuert; den tredje måde ville være at konstruere de to ure med en sådan kunst og præcision, at man kunne være sikker på deres efterfølgende overensstemmelse" (Leibniz, 1866, s. 548). Ved systematisk at tilbageholde kun den første, eller højst den anden af disse hypoteser - hvis man tildeler et parti eller en karismatisk leder rollen som Deus ex machina - ignorerer man den sikreste fundering af integrationen af grupper eller klasser: Praktikkerne hos medlemmerne af den samme gruppe eller klasse er altid mere og bedre harmoniseret, end agenterne selv ved eller vil have det, fordi, som Leibniz siger, "ved kun at adlyde sine egne love", er enhver "ikke desto mindre harmoniseret med den anden" (Leibniz, 1866). Habitus er intet andet end denne immanente lov, lex insita, bundfældet i enhver agent ved hans basale lærdom, som ikke kun er betingelsen for praktikkernes samstemmighed, men også for overensstemmelsens praktikker: Ensretningen og tilpasningen, som bevidst udføres af agenterne, forudsætter mestringen af en fælles kode, og tilløb til kollektive mobiliseringer kan ikke lykkes uden et minimum af overensstemmelse mellem habitus hos de mobiliserende agenter (f.eks. profet eller partileder etc.) og dispositionerne hos dem, hvis håb de prøver at udtrykke. Langt fra at praktikkernes samstemmighed altid er produktet af overensstemmelse, kan en af de primære funktioner af orkestreringen af habitus være at tillade en overflødiggørelse af "intention" og af den "intentionelle overførsel til den Anden" ved at muliggøre en slags praktisk behaviourisme, der, i de fleste situationer i livet, fritager en fra nærmere analyser af nuancerne i en andens opførsel eller fra direkte undersøgelser af hans intentioner ("hvad mener du?"): Ligesom én, der poster et brev, simpelthen forudsætter, som Alfred Schutz har vist det, at anonyme funktionærer vil opføre sig anonymt, i overenstemmelse med deres anonyme intention, på samme måde som den, der accepterer penge som et bytte-middel, implicit regner med, at andre agenter, som Max Weber viser det, vil samtykke $i$ at anerkende disses funktion. Automatisk og upersonligt, meningsfuld uden at have til formål at være det, er den almindelige livsopførsel velegnet til en ikke mindre automatisk og upersonlig dekodning: Den objektive intentions dekodning, som de udtrykker, kræver på ingen måde "reaktiveringen" af intentionen "erfaret" af den person, som fuldbyrder denne opførsel. ${ }^{12}$

Enhver agent producerer og reproducerer den objektive mening: Fordi hans handlinger er produktet af en modus operandi, som han ikke producerer og ikke mestrer bevidst, indeholder de, som skolastikerne siger en "objektiv intention", der altid overgår hans bevidste intentioner. Således kan, præcis som det er vist af Gelb og Goldstein, visse afatikere, som har mistet evnen til at vække ordet eller begrebet ud fra betydningen, utilsigtet udtale formuleringer, hvori de først senere genkender den krævede respons, således at de internaliserede tanke- og udtryks-skemaer muligg ør den intentionsløse opfindelse af en reguleret improvisation, hvis udgangs- og støttepunkter ligger i

\footnotetext{
${ }^{11}$ Se appendix.

12 Det er en af subjektivismens og moralismens meriter, at den per absurdum, i analyser, hvor den fordømmer handlinger, der er underkastet verdens objektive fristelser, som uautentiske (hvad enten det drejer sig om Martin Heideggers analyse af daglig eksistens og af "das Man" eller Satres analyse af "the spirit of seriousmindedness"), demonstrerer umuligheden af den "uautentiske" eksistens, der i et projekt af frihed ville samle alle de forud givne bestemtheder og objektive determineringer.
} 
færdiglavede formler såsom ordpar eller kontrasterende billeder: ${ }^{13}$ Stadigt indhentet af sine egne ord, med hvilke han ifølge Nicolai Hartmann fører et "bær og bliv båret" -forhold, opdager virtuosen i sit opus operatum nye stikord og nye støtter for det modus operandi, af hvilket hans diskurs er produktet på en sådan måde, at den vedvarende giver næring til sig selv som et tog, der medbringer sine egne skinner (Ruyer, 1966, s. 136). Vittigheder overrasker ikke deres ophavsmænd mindre end deres publikum, og de gør lige så stort indtryk ved deres retrospektive nødvendighed som ved deres nyhed, fordi opdagelsen fremtræder som den simple åbenbaring, både tilfældig og uundgåelig, som en immanent mulighed i sprogets strukturer. Fordi subjekterne rent ud sagt ikke ved, hvad de gør, har det, de gør, mere mening, end de forventer. Habitussen er den universaliserende formidling, som gør praktikker, der hverken har eksplicit grund eller signifikant intention, 'fornuftige', 'rimelige' og objektivt orkestrerede: Den del af praktikkerne, som set med deres egne producenters $\varnothing$ jne forbliver skjult, er det aspekt, hvorved de bliver objektivt tilpasset til de andre praktikker og strukturer, og af hvilke principperne for deres egen produktion selv er et produkt. For at blive færdig med sludderen om 'forståelsen', som konstituerer den sidste udvej for dem, der forsvarer retten til subjektiviteten imod humanvidenskabernes 'reduktive' imperialisme, behøver vi bare at huske på, at afkodningen af praktikkernes og værkernes objektive intention intet har at gøre med "reproduktionen" (Nachbildung ifølge den unge Wilhelm Dilthey) af subjektive erfaringer og den nytteløse og usikre rekonstruktion af de personlige singulariteter.

Fordi de er produktet af dispositioner, der er objektivt samstemmende, idet de er internaliseringen af samme objektive strukturer, besidder praktikkerne hos medlemmerne af den samme gruppe eller af den samme klasse i et differentieret samfund en objektiv mening, som både er ens og systematisk, idet den overskrider subjektive intentioner og bevidste individuelle eller kollektive projekter: ${ }^{14}$ Med andre ord kan objektifikationsprocessen ikke beskrives i sproget for interaktion og gensidig tilpasning, fordi selve interaktionen skylder sin form til de objektive strukturer, som producerede de interagerende agenters dispositioner, og som tildeler dem deres relative positioner i interaktionen og andre steder. Det tilsyneladende grænseløse univers af teorier om kulturindlæringer og kulturelle kontakter kan reduceres til en modsætning mellem realismen af ideer og realismen af det sanselige. Den første kategori af teorier behandler kulturelle eller lingvistiske ændringer som resultatet af kontakter mellem kulturer og sprog, underlagt love, som er generelle, eksempelvis loven om restruktureringen af lån, eller specifikke, eksempelvis dem, der etableres ved analysen af strukturer specifikke for de sprog eller kulturer, der er i kontakt. Realismen i det sanselige understreger kontakten mellem de involverede samfund (i betydningen populationer, der kan reduceres til et sæt af individer) og ignorerer det meste af tiden selv de objektive strukturer i relationerne mellem de samfund, som konfronterer hinanden (dominans etc.). I hver enkelt konfrontation mellem to individuelle agenter eller grupper (f.eks. en chef der giver ordrer til en underordnet, kolleger der taler om deres elever, intellektuelle der deltager i et symposium etc.), dvs.

\footnotetext{
${ }^{13}$ Hvis det ikke udgjorde en rudimentær, og derfor økonomisk og praktisk form, ville tanker formuleret som par sandsynligvis være mindre hyppige i almindeligt sprog, og selv i forskningssprog, begyndende med antropologernes sprog, ville det stadig være domineret af talrige falske dikotomier, såsom individet og samfundet, personlighed og kultur, fællesskab og samfund, 'folkelig' og 'urban' etc., hvilke er lige så utilstrækkelige som de mest traditionelle filosofiske dikotomier, såsom materie og ånd, krop og sjæl, teori og praktik etc. (jf. Bendix \& Berger, 1959).

${ }^{14}$ Var dette sprog ikke på anden måde farligt, kunne man være fristet til at sige, modsat alle former for subjektivistisk voluntarisme, at enheden af en klasse fundamentalt hviler på det "klasse-ubevidste": "Bevidsthed" er ikke en indstiftende handling, som konstituerer klassen i en glans af frihed; dens eneste effektivitet, som i alle symbolsk duplikerende handlinger, stammer fra det omfang, den fører alt det, der implicit antages vedrørende den ubevidste form i klassehabitus, op på det bevidste niveau.
} 
i enhver interaktion struktureret af de objektive strukturer i forholdene mellem de korresponderende grupper (f.eks. kolonisator og koloniseret), konfronteres generelle habitusser (båret af biologiske individer): Interaktion opstår mellem systemer af dispositioner såsom sproglig kompetence og kulturel kompetence, og gennem denne habitus, mellem alle de objektive strukturer de er et produkt af, og især strukturerne i systemerne af symbolske relationer, såsom sprog. På denne måde er strukturerne i de involverede fonologiske systemer kun aktive (som det er bevidnet, f.eks. af accenten hos ikke-indfødte brugere af det dominante sprog), hvis de er inkorporeret i en kompetence erhvervet i løbet af en individuel historie (hvor de forskellige former for tosprogethed er et resultat af forskellig former for erhvervelse) inden for en læreproces, som implicerer en selektiv $\mathrm{d} \emptyset$ vhed og systematiske restrukturerende handlinger.

At tale om klasse-habitus (eller om 'kultur' i betydning kulturel kompetence erhvervet inden for en homogen gruppe) er derfor en advarsel mod alle former for den okkasionalistiske illusion, som består i direkte at relatere praktikkerne til egenskaberne indeholdt i situationen: "Interpersonelle" relationer er aldrig, individ til individ relationer, selvom det virker sådan, og sandheden om interaktionen ligger aldrig fuldstændigt i selve interaktionen. Socialpsykologien, interaktionismen og etnometodologien overser dette, når de reducerer den objektive struktur i forholdet mellem sammenbragte individer til deres interaktions tilfældige struktur i en speciel situation og gruppe, og fors $\emptyset$ ger at forklare alt det der sker i en eksperimentel eller observeret interaktion med situationens eksperimentelt kontrollerede karakteristika, såsom deltagernes relative position i rummet eller de udnyttede kanalers beskaffenhed. De biologiske individer bærer til enhver tid og på ethvert sted den fortidige og nutidige position i den sociale struktur med sig i form af habitussen. Dispositionerne ses som tegn på sociale positioner og derfor på den sociale distance mellem objektive positioner, eller for at sige det på en anden måde, mellem de tilfældigt sammenbragte (i fysisk rum, hvilket ikke er det samme som socialt rum) sociale personer. Dispositionerne ses som påmindelser om denne distance og om den opførsel, der er nødvendig for strategisk at manipulere sociale distancer, symbolsk eller $\mathrm{i}$ realiteten, for at mindske dem (hvilket er lettere for den dominerende agent end for den dominerede) eller $\varnothing$ ge dem, eller helt enkelt at opretholde dem (ved at undgå "at tillade fortroligheder", eller kort sagt, ved "at holde fast på sin ære", eller modsat ved at undgå "at tage sig friheder" og, med andre ord, ved at "forblive på sin plads").

Selv de former for interaktion, som mest åbenbart er modtagelige for beskrivelser $\mathrm{i}$ termer af den "intentionelle overførsel til den Anden", såsom sympati, venskab eller kærlighed, domineres gennem mellemkomst af harmonien i habitus eller, mere præcist, i etos og smag - utvivlsomt opfattet gennem de umærkbare indikationer fra den kropslige exis - ved den objektive struktur af relationerne mellem betingelser og positioner, som de bekræftes gennem klasse-homogami. Illusionen om valgfri affinitet eller gensidig prædestination opstår af uvidenhed om de sociale betingelser for harmonien i æstetiske smag eller etiske tilbøjeligheder, således opfattet som bevis for de ubeskrivelige affiniteter, de er ophav til. Kort sagt, habitussen er et produkt af historie, og producerer individuelle og kollektive praktikker, og derfor historie, i overensstemmelse med de generative skemaer genereret af historien. Habitussen opererer mere præcist som en fortid, der har overlevet ind i nutiden og tenderer mod at forevige sig ind i fremtiden ved at generere praktikker struktureret $\mathrm{i}$ overensstemmelse med dens principper, og som den interne lov, gennem hvilken loven om eksterne $\mathrm{n} \emptyset$ dvendigheder, der er irreducerbare til omstændighedernes umiddelbare tvang, kontinuert opererer. Habitussen genererer på den ene side den kontinuitet og den regelmæssighed, som objektivismen observerer i den sociale verden uden at være i stand til at præsentere en rationel forklaring på dem, og på den anden side de regulerede transformationer og revolutioner, som hverken den mekaniske sociologismes ydre og øjeblikkelige determinisme eller den tilsvarende øjeblikkelige, men rent indre determination, såsom den voluntaristiske eller spontanistiske subjektivisme tænker sig den, er i stand til at gøre rede for. 
Det er lige sandt og usandt at sige, at kollektiv handling producerer begivenheden eller at den er produktet af hændelsen: Faktisk er de produktet af en konjunktur, dvs. af den nødvendige sammenføjning af dipositioner og en objektiv hændelse. F.eks. fremkalder den betingende stimulering af den revolutionære konjunktur en bestemt respons fra alle dem, der opfatter den som sådan, dvs. dem, der er prædisponerede til at opfatte den som sådan, fordi de besidder en bestemt type habitus, som kan være duplikeret og forstærket ved opvågningen af en klasse-bevidsthed, dvs. direkte eller indirekte besidder en form for diskurs, der er i stand til at sikre en symbolsk mestring af de praktisk mestrede principper for klasse-habitus. ${ }^{15}$ Den konjunktur, som er i stand til at transformere praktikker, der er objektivt koordinerede, fordi de er delvist tilpasset eller helt identiske med objektive nødvendigheder, til kollektiv handling, er produktet af det dialektiske forhold mellem dispositionerne og begivenheden. Uden nogensinde at være totalt koordinerede er dispositionerne og situationerne, som er synkront kombineret til at konstituere en bestemt konjunktur, aldrig helt uafhængige, fordi de er produktet af "kausale serier" karakteriseret ved forskellige strukturelle varigheder, fordi de er skabt af objektive strukturer, dvs. af økonomiske strukturer i den sidste ende: Trægheden (hysteresis) i habitus, som er forudsat af reproduktionsprocessen af strukturerne inden for habitus, er et af fundamenterne for det strukturelle gab mellem muligheder og dispositionerne for at begribe dem, som fører til manglende muligheder, og i særdelsehed til den manglende evne til at analysere historiske kriser i overensstemmelse med andre, selv revolutionære, perceptionskategorier end fortidens.

De objektive strukturer er altså produkter af historiske praktikker kontinuert reproducerede (med eller uden transformeringer) af historiske praktikker, hvis reproduktive princip selv er produktet af strukturer, som det derfor tenderer mod at reproducere. Når man er uopmærksom på det dialektiske forhold mellem de objektive strukturer og de kognitive og motiverende strukturer, de producerer, og som tenderer mod at reproducere de objektive strukturer, har man intet andet valg end at reducere forholdet mellem de forskellige sociale agenturer - set som "forskellige oversættelser af den samme sætning", i overensstemmelse med en spinozisk metafor - til den logiske formel. Dette tillader os at genopdage en hvilken som helst af dem på basis af en hvilken som helst anden og at finde princippet for udviklingen af strukturer i en slags teoretisk partenogenese, således at der tilbydes Hegel, hans Historiens Philosophie (Hegel, 1842) og lanceringen af begrebet Weltgeist en uventet revanche, idet den "ånd" "udvikler sin unikke beskaffenhed", mens den altid forbliver identisk med sig selv. Så længe man accepterer den kanoniske modsætning, som kontinuerligt genopstår i nye former gennem hele historien om social tænkning og i dag f.eks. placerer den 'humanistiske' fortolkning af den unge Marx i modsætning til 'strukturalistiske' læsninger af Kapitalen (Marx, 1970-72), kan man kun undslippe subjektivisme ved at forfalde til sociallovs-fetichisme: Ved at etablere forholdet mellem det potentielle og det aktuelle, mellem partituret og opførelsen, mellem essensen og eksistensen, mellem struktur og praktik, erstatter objektivismen blot et menneske undertvunget de $\mathrm{d} \varnothing \mathrm{de}$ naturhistoriske love med subjektivismens skabelses-menneske. Det udfordrende ved individet, betragtet som ens realissimum, fører blot til, at det behandles som et epifænomen i en hypostaseret struktur, og påstanden om det primære i de objektive relationer fører til, at disse produkter af menneskelig aktivitet - strukturer - gives magten til at udvikle sig i overensstemmelse med deres egne love og til at determinere, eller overdeterminere, andre strukturer. Problemet er ikke nyt, og

\footnotetext{
${ }^{15}$ Illusionen om fri skaben kan muligvis finde en del af sin berettigelse i alle betingende stimuleringers karakteristiske cirkel: Habitus kan kun være ophav til den type af respons objektivt indeholdt i dens logik, så længe den giver sin effektivitet som et stikord til konjunkturen ved at konstituere den i overensstemmelse med dens egne principper, med andre ord, ved at få den til at eksistere som et spørgsmål refererende til en speciel forståelse af, hvad det indebærer at stille spørgsmål til virkeligheden.
} 
forsøget på at overskride modsætningen mellem subjektivisme og objektivisme er altid stødt mod den epistemologiske hindring, individet, stadig i stand til at hjemsøge teorien om historien, selv når det, med Friederich Engels, reduceres til den tilstand af molekyler, der i sit forhold til andre molekyle1er, i en art brownsk bevægelse, producerer en objektiv mening reducer bar til den mekaniske sammensætning af enkeltstående tilfældigheder. ${ }^{16}$

Ligesom modsætningen mellem sprog og tale som simpel udførsel, eller i det mindste som forkonstrueret objekt, maskerer modsætningen mellem sprogets objektive relationer og dispositionerne for den lingvistiske kompetence, så hindrer modsætningen mellem struktur og individ (imod hvilken struktur skal erobres, og erobres om og om igen) konstruktionen af det dialektiske forhold mellem habitussens strukturer og dispositioner. Habitussen er produktet af arbejdet med indprentning og tilegnelse, som er $n \varnothing d v e n d i g$ for at muligg $\varnothing$ re reproduktionen af disse produkter af kollektiv historie: Takket være dette arbejde vil objektive strukturer (f.eks.- sproglige, $\emptyset$ konomiske etc.) reproducere sig selv i form af varige dispositioner i alle individuelle organismer (som man kan kalde individer), varigt underkastet de samme betingelser, og derfor placeret i de samme materielle eksistensbetingelser. Med andre ord behandler sociologien alle de biologiske individer, der, som et produkt af de samme objektive betingelser, handler som støtter for den samme habitus, som identiske: Sociale klasser set som et system af objektive relationer skal ikke relateres til individet eller til "klassen" som en population, dvs. som en sum af tællelige og målelige biologiske individer, men til klasse-habitussen som et system af dispositioner, der er (delvist) fælles for alle produkterne af de samme strukturer. Hvis ikke det er muligt, at alle medlemmer af den samme klasse (eller selv to af dem) kan have haft de samme erfaringer i den samme rækkefølge, er det ikke desto mindre klart, at ethvert medlem af den samme klasse har en st $\varnothing$ rre chance end ethvert medlem af en anden klasse for at være blevet konfronteret, enten som agerende eller som et vidne, med de situationer, som er mest almindelige for medlemmerne af denne klasse. De objektive strukturer, som videnskaben begriber i form af statistiske regelmæssigheder (f.eks. i form af arbejdsløshedstal, indkomstkurver, chancer for adgang til videregående uddannelser etc.), og som giver sin fysiognomi til et socialt landskab med dets lukkede karrierer, dets 'utilgængelige' positioner, dets 'blokerede horisonter', indprenter via lignende erfaringer "kunsten at evaluere sandsynligheder", som Leibniz kalder det, hvilket betyder, at foregribe det, som objektivt set er ved at ske, kort sagt den bestemte sans for realitet eller realiteter.

Forholdet mellem klasse, habitus og organisk individualitet, som aldrig helt kan fjernes fra den sociologiske diskurs - for så vidt som det står umiddelbart til rådighed for perception (intuitus personae), men også er socialt navngiven og anerkendt (navn, juridisk person etc.), og for så vidt som det er defineret af en social livsbane, der ikke kan reduceres til noget andet - kan i det mindste udtrykkes metaforisk inden for den transcendentale idealismes sprog, som de, der bruger begrebet om det ubevidste, af og til implicit gør det. Overvejer man habitus som et subjektivt, men ikke

\footnotetext{
16 "Historien er skabt på en sådan måde, at det endelige resultat altid dukker op i konflikten mellem et stort antal individuelle viljer, hvoraf hver enkelt efter tur er gjort til det, den er, som resultatet af en hoben specifikke eksistensbetingelser; i den, som en konsekvens, krydser utallige kræfter gensidigt hinanden, en uendelig gruppe af kræfternes parallelogrammer, fra hvilke et resultat opstår - den historiske begivenhed - som efter tur kan ses som produktet af en kraft, der virker som et hele, ubevidst og blindt. Fordi det, et individ $\emptyset$ nsker, obstrueres af ethvert andet individ, og hvad der opstår er noget, ingen ønskede. På denne måde har historien indtil nu udfoldet sig som en naturlig proces og er også underkastet, $i$ sin helhed, de samme bevægelseslove" (Engels, 1890). Mennesket skaber selv sin historie, men ikke, indtil nuet, med den kollektive vilje i en overordnet plan, selv ikke i et givet, klart begrænset samfund. Deres bestræbelser ophæver hinanden, og det er præcis derfor $n \varnothing d v e n d i g h e d$, fuldendt og udtrykt af tilfældet, regerer i alle samfund af denne type" (Engels, 1894).
} 
individuelt system af internaliserede strukturer vedrørende perception, forestilling og handling skemaer fælles for alle medlemmerne af den samme gruppe eller klasse, som konstituerer betingelserne for objektifikation - er vi i dette perspektiv nødt til at fundere den objektive samstemmighed mellem praktikkerne og det unikke i verdenssynet på den perfekte upersonlighed og udskiftelighed af singulære praktikker og syn. Men det vil være ensbetydende med at påstå, at alle praktikker eller syn produceret af identiske skemaer er upersonlige og udskiftelige, idet de er individuelle intuitioner om rum, der ifølge Immanuel Kant ikke afspejler nogen af de særegenheder ved det empiriske ego. Faktisk er diversiteten inden for homogenitet, som er karakteristisk for den individuelle habitus hos de forskellige medlemmer af den samme klasse, og som reflekterer diversiteten inden for homogeniteten af de sociale betingelser for produktionen af disse habitusser, baseret på det fundamentale homologiske forhold, som udvikles mellem habitus hos medlemmerne af en enkelt gruppe eller klasse, fordi de er produktet af internaliseringen af de samme fundamentale strukturer: Homologien i verdenssyn, for at bruge et af Leibniz's udtryk, svarende til identiteten af perceptuelle skemaer, udelukker ikke de systematiske forskelle, der adskiller individuelle verdenssyn udviklet fra individuelle - og alligevel samstemmige - synspunkter.

På grund af selve logikken for dens genese, er habitus en kronologisk ordnet serie af strukturer, en struktur af bestemt rang, der specificerer strukturerne af lavere rang (og derfor er genetisk forudgående), og strukturerer de højere rangerende strukturer gennem dets strukturerende virkning på de strukturerede erfaringer, som genererer disse strukturer: Således giver eksempelvis den habitus, der er erhvervet i familien, sin struktur til skoleerfaringer (og især til modtagelsen og tilegnelsen af det specifikt uddannelsesmæssige budskab). Den familiale habitus, transformeret af selve skolens virkning, giver efter tur sin struktur til alle følgende erfaringer (f.eks. til modtagelsen og tilegnelsen af budskaber produceret og spredt af kulturindustri, eller professionelle erfaringer). Disse erfaringer integreres i enheden af en systematisk biografi, som er udviklet på basis af den oprindelige klasse-situation erfaret i en bestemt type af familiestruktur. Den individuelles historie er aldrig mere end en specifik del af hans gruppes eller klasses kollektive historie, og som konsekvens heraf er systemerne af individuelle dispositioner strukturelle varianter af gruppens eller klassens habitus, systematisk arrangeret selv i de forskelle, som adskiller dem, og som reflekterer forskellene mellem livsforløb og positioner inden for eller uden for klassen. "Personlig" stil, dvs. det bestemte mærke, som bæres af alle produkter af en enkelt habitus, praktikker eller værker, er simpelthen en afvigelse, selv reguleret og af og til ovenikøbet kodificeret i forhold til en periodes eller klasses stil. Som sådan refererer den tilbage til den fælles stil, ikke kun ved sin konformitet, som Phydias, der ifølge Hegel ikke havde nogen "stil", men også ved den forskel "stilen" udgør.

\section{Appendix}

Jean-Paul Sartre giver et ultra-subjektivistisk svar på det rituelle spørgsmål, der ligger under den endeløse debat om subjektivisme og objektivisme. Idet han behandler revolutionær bevidsthed som produktet af en slags imaginær variation, påstår han, at den besidder magten til at skabe nutidig mening ved at skabe den revolutionære fremtid, der negerer den:

For det er nødvendigt her at vende op og ned på den almindelige opinion og på basis af hvad den ikke er at anerkende en situations skånselsløshed eller de lidelser den påtvinger, hvilke begge er motiver til at opfatte en anden tingenes tilstand, i hvilken tingene ville være bedre for enhver. Det er den dag hvor vi kan begribe en ny tingenes tilstand, at nyt lys falder på vores besværligheder og vores lidelser og at vi beslutter os for at de er ubærlige. (Sartre, 1957, s. 434-435) 
Ved at have ignoreret eller fornægtet spørgsmålet om de økonomiske og sociale betingelser for opkomsten af bevidstheden om de økonomiske og sociale betingelser, kan Sartre ved handlingens oprindelse sætte en absolut handling, der tildeler mening, en "opfindelse" eller en omvendelse, (Sartre, 1953). Hvis handlingens verden ikke er andet end et imaginært univers af udskiftelige muligheder, der er fuldstændigt afhængig af bevidsthedens bestemmelser, som skaber den, og derfor totalt fri for objektivitet, hvis det bevæger sig fordi subjektet vælger at lade sig bevæge, hvis det rejser sig, fordi det vælger at lade sig rejse, så er følelser, passioner og handlinger kun spil af "ond tro" og af "ånden af alvor", triste farcer, hvor man både er den dårlige skuespiller og det gode publikum:

Det er ikke tilfældigt, at materialismen er alvorlig; det er ikke tilfældigt, at den findes til alle tider og steder som den revolutionæres favorit-doktrin. Det er, fordi de revolutionære er alvorlige. De kommer til at kende sig selv, først i termer af den verden, som undertrykker dem [...] Den alvorlige mand er 'af verden' og har ingen ressourcer i sig selv. Han forestiller sig end ikke længere muligheden for at slippe ud af verden [...] han er i ond tro. (Sartre, 1957, s. 580)

Den samme uduelighed til at behandle "alvor" på anden måde end som den afviste form af "ånden af alvor" kan ses i en analyse af følelsen, der i bogen L'imaginaire skilles fra den mindre radikalt subjektivistiske i den anden af Sartres bøger om følelser: Fænomenologi og følelser: Fors $\varnothing g$ på en følelsernes teori:

Hvad får mig til at beslutte mig til at vælge det magiske aspekt eller det tekniske aspekt af verden? Det kan ikke være verden selv, fordi den, for at blive manifesteret, venter på at blive opdaget. Derfor er det nødvendigt, at dette for-sig-selv i dets projekt må vælge at være den, der opdager verden som magisk eller rationel; dvs. dette for-sig-selv, som et frit projekt af sig selv, må give sig selv magisk eller rationel eksistens. Det er ansvarligt for begge, for dette for-sig-selv kan kun være, hvis det har valgt sig selv. Derfor findes dette for-sig-selv som det fri fundament for dets følelser såvel som for dets villen. Min frygt er fri og manifesterer min frihed. (Sartre, 1957, s. 445)

Denne handlings-teori burde uundgåeligt føre til det desperate projekt om samfundets og om historiens transcendentale genese (man genkender her den Critique de la raison dialectique kritikken af den dialektiske fornuft, Sartre, 1960), som Durkheim synes at pege mod, når han skriver:

Det er fordi det imaginære ikke byder ånden nogen modstand, at ånden der ingen modstand føler, hengiver sig til grænseløse ambitioner og tror på muligheden af at konstruere, eller snarere af at rekonstruere verden, alene med dens egen styrke og i overensstemmelse med dens ønsker. (Durkheim, 1895, s. 18)

Selvom vi til denne analyse af Sartres antropologi kan modstille talløse tekster (især blandt hans tidligste og hans seneste arbejder), i hvilke Sartre anerkender eksempelvis den "passive syntese" af et univers af allerede konstituerede betydninger, eller i hvilke han udtrykkeligt forkaster selve principperne i sin filosofi, såsom den passage fra L'être et le néant (Sartre, 1943, s. 543) hvor han $\emptyset$ nsker at blive betragtet som adskilt fra Rene Descartes' øjebliks filosofi eller sætningen fra Critique de la raison dialectique (Sartre 1960, s. 161), hvor han annoncerer et studium af "agentløse handlinger af totalisationer, der ikke har nogen totalisator, af mod-finaliteter, af ondartede cirkler", så afviser Sartre ikke desto mindre, og med fysisk afsky,

disse gelatinøse realiteter, mere eller mindre vagt hjemsøgte af en supra-individuel bevidsthed, som den skamfulde organicisme stadig, mod enhver sandsynlighed, forsøger at genfinde i det rå, komplekse men skarptskårne felt af passiv aktivitet, hvor der er individuelle organismer af uendeligt antal og uorganiske materielle realiteter. (Sartre, 1960, s. 305) 
Fordi den er essentialistisk tildeles objektiv sociologi den meget suspekte opgave at studere "inertiens socialitet", dvs. klasse reduceret til inertia, og derfor til afmagt ("impotens"), klasse som en ting, "viskøs" og "klæbende" i dens væren, med andre ord i dens "havende været":

Klasseserialiteten ændrer den enkelte (ligegyldigt hvem han er og hvad hans klasse er) til et væsen der definerer sig selv som en humaniseret ting [...] Den anden form for klasse, dvs. den gruppe der tilsammen bliver en praxis, er født i hjertet af den passive form og som dens negation. (Sartre, 1960, s. 357)

Den sociale verden, der rummer sådanne "bastard-kompromiser" mellem tingen og meningen, som definerer "objektiv mening" som mening transformeret til ting, konstituerer en positiv udfordring til dem, der kun er i stand til at ånde i bevidsthedens eller den individuelle "praxis"' rene og transparente univers. Denne artificialisme anerkender ingen anden grænse for egoets frihed end den som friheden på tvinger sig selv gennem den fri frasigelse ved en ed eller ved hengivelse til" ond tro", den sartreske term for fremmedgørelse, eller den grænse, som "alter ego"ets fremmedgørende frihed påtvinger den i hegelianske kampe mellem herre og slave; som en konsekvens, ude af stand til i "sociale arrangementer" at se" andet end kunstige og mere eller mindre vilkårlige kombinationer", som Durkheim siger det (Durkheim, 1895, s. 19), underordner han uden eftertanke transcendensen af det sociale - reduceret til det "reciprokke af tvang og autonomier" - til "transcendensen af egoet". Som den tidlige Sartre sagde:

I dette handlingsforløb ser individet det dialektiske som rationel transparens, for så vidt som han producerer det, og som absolut nødvendighed for så vidt som det undslipper ham, med andre ord som helt enkelt, for så vidt som andre producerer det; endelig, for så vidt som han ved at overskride sine behov anerkender sig selv, anerkender han den lov, der påtvinges ham ved andres overskriden af deres behov (at sige, at han anerkender dem, er derimod ikke at sige, at han underkaster sig dem), han anerkender sin egen autonomi (for så vidt som den kan blive brugt af en anden, og for så vidt den dagligt ses i form af bluff, manøvrer etc.) som en fremmed magt, og andres autonomi som den ubønhørlige lov, som tillader ham at tvinge dem. (Sartre, 1960, s. 133)

Transcendensen af det sociale kan kun være en effekt af "gentagelse", dvs. ifølge den sidste analyse af antal (derfor den vigtighed, der tillægges "serier") eller af "materialiseringen af gentagelse" i kulturelle objekter (Sartre, 1960, s. 234 og 281), i form af fremmedg $\varnothing$ relse, der består i den fri afgivelse af frihed til fordel for kravene fra "bearbejdet stof":

Det 19. århundredes arbejder gør sig selv til det som han er, dvs. han praktisk og rationelt bestemmer størrelsesordenen af sine omkostninger - derfor bestemmer han inden for sin fri praksis - og gennem denne frihed skaber han sig selv som det han var, det han er, og det han skal være: En maskine, hvis løn ikke beløber sig til mere end de løbende udgifter[...] Klasseværen som en praktik-træg væren kommer til mennesker gennem mennesker, gennem den passive syntese af bearbejdet stof. (Sartre, 1960, s. 294)

Andetsteds fører det at hævde det "logiske" primat af den "individuelle praksis", opfattet som den konstituerende fornuft fremfor at hævde det "logiske primat" af historien som den konstituerede fornuft, til at vi anskuer problemet om samfundets opkomst i samme termer, som tilhængerne af teorien om samfundspagten.

Historien determinerer indholdet af menneskelige relationer $i$ sin totalitet, og disse relationer [...] henviser til alt. Men menneskelige relationer er, generelt, ikke resultatet af Historien. Det er ikke problemer med organiseringen og arbejdsdelingen, der har ført til udviklingen af forhold mellem de primært separerede objekter, nemlig mennesker. (Sartre, 1960, s. 179) 
Sartre siger i overensstemmelse med Descartes: "Skabelse er kontinuert, som Jean Wahl siger det, fordi varighed ikke er det", og fordi udbredt substans ikke i sig selv indeholder magten til fortsat at bestå, tildeles Gud en kontinuert fornyet opgave i at skabe verden ex nihilo, ved en fri viljeshandling, således at den typiske kartesianske afvisning af den viskøse uigennemsigtighed af "objektive potentialiteter" og af objektiv mening fører Sartre til at overlade den udefinerede opgave med at rive det sociale hele, eller klassen, bort fra trægheden i den "praktik-træge" til det absolutte initiativ hos de "historiske agenter", hvad enten disse er individuelle eller kollektive, såsom "Partiet", der er en hypostase af det sartreske subjekt. Ved slutningen af hans umådelige imaginære roman om døden og frihedens genopstandelse, - med dens duale bevægelse mellem 1) "eksternaliseringen af internalitet", der fører fra frihed til fremmedgørelse, fra bevidsthed til materialiseringen af bevidsthed eller, som titlen siger det, "fra praksis til det praktik-træge", og 2) "internaliseringen af eksternalitet", som ad bratte genveje, over opvækkelsen af bevidstheden og "fusionen af bevidstheder", fører "fra gruppen til historien", fra den fremmedgjorte gruppes tingsliggjorte tilstand til den autentiske eksistens af den historiske agent - er bevidsthed og ting lige så uhelbredeligt adskilt i udgangspunktet, uden at der nogensinde har været nogen mulighed for at observere eller konstruere noget, der ligner en institution eller et symbolsk system i betydningen af et autonomt univers (selve valget af eksempler bekræfter dette). Opkomsten af en dialektisk kurs (som ikke er andet end den dialektiske opkomst af diskurs) kan ikke skjule de uendelige svingninger mellem den som er "i-sig-selv" og den som er "for-sig-selv" eller, i det nye sprog, mellem materialitet og praktik, mellem gruppens inerti reduceret til dens essens, med andre ord til, dens udlevede fortid og til dens nødvendighed (som bliver overladt til sociologer), og den kontinuerte skabelse af det fri kollektive projekt, set som en serie af besluttende handlinger, uundværlige for at redde gruppen fra tilintetg $\varnothing$ relsen til ren materialitet. Imod forfatterens subjektive intentioner, imod et permanent projekt om "omdannelse" er de objektive intentioner i sartresk filosofi opfyldt med visse forskelle i sprog, men aldrig så åbenbare og åbenbart oprigtige som i visse af hans fordømmelser, der sandsynligvis ville være mindre voldsomme, hvis de i mindre grad antydede bevidst eller ubevidst selvkritik. Således må man eksempelvis huske på den berømte analyse af café-tjeneren for fuldt ud at værdsætte en sætning som denne:

For alle dem, der antager sig selv for engle, må deres naboers aktiviteter forekomme absurde, på grund af den førstnæuntes krav på at overskride det menneskelige foretagende ved at nægte at deltage i det (Sartre, 1960, s. 182-183).

Konstansen i omdannelses-projektet finder sit princip i permanensen af habitus, som gør dette projekt på samme tid $n \varnothing$ dvendigt og nødvendigvis d $\varnothing \mathrm{mt}$ til at mislykkes. Sartres teori om Gustave Flauberts forhold til bourgeoisiet er nok det mest åbenbare og mest direkte udtryk for bourgeoisiets forhold til eksistens og til de materielle betingelser for eksistens, som ved at gøre opvækkelsen af bevidstheden til generator for en eksistens og et værk, demonstrerer, at det ikke er tilstrækkeligt at blive bevidst om sine klassebetingelser for at kunne befri sig fra de varige dispositioner, den producerer (jf. Bourdieu, 1971, især s. 12-14). Projektet med at udvikle en "handlings-sociologi", defineret som "friheds-sociologien" - et udtryk allerede benyttet af Pierre G. F. Le Play - tilhører, mutatis mutandis, den samme logik (jf. Touraine, 1965, 1966). Afvisningen af den "reduktive" definition på sociologi finder her de evige temaer og sprog, fra hvilke Bergson hentede arketypen om det lukkede og det åbne, om kontinuitet og brud, rutine og skabelse, institutionen og personen. 


\section{Referencer}

Aron, R. (1965). Catégories dirigeants ou classe dirigente?. Revue francaise de science politique, 15 (1), s. 7-27.

Aron, A. (1965). Démocratie et totalitarisme. Paris: Gallimard.

Bendix, R. \& Berger, P. (1959). Images of society and problems of concept formation in sociology. In: Gross, L. (Red.). Symposium on sociological theory (s. 92-118). New York: Harper and Row.

Bourdieu, P. (1973). The three forms of theoretical knowledge. Social Science Information. 12 (1), s. 53-80.

Bourdieu, P. (1971). Champ du pouvoir, champ intellectuel et habitus de classe. Scolies, 1, s. 7-26.

Bourdieu, P. (1994/2008) De tre former for teoretisk viden. I Callewaert, S., Munk, M., Nørholm, M. og Petersen A.K. (Red.) Pierre Bourdieu. Centrale tekster inden for sociologi og kulturteori. (s.72108)København: Akademisk Forlag/Frydenlund.

Chapple, E.D. \& Coon, C.S. (1947). Principles of anthropology. London: Jonathan Cape.

Cournot, A. (1922). Essai sur le fondements de la connaissance et sur les caractères de la critique philosophique. Paris: Hachette.

Durkheim, E. (1938). L'évolution pédagogique en France. Paris: Alcan.

Durkheim, E. (1956). Les règles de la methode sociologique. Paris: Presses Universitaires de France.

Durkheim, E. (1895). Les règles de la méthode sociologique. Paris: Alcan.

Engels, F. (1890). Letter to Joseph Bloch. 21. september.

Engels, F. (1894). Letter to Hans Starkenburg. 5. januar.

Harris, M. (1951). Review of selected writings of Edward Sapir, language, culture and personality. Language, 27 (3), s. 288-333.

Harris, M. (1964). The nature of cultural things. New York: Random House.

Hegel, G.W.F. (1842). Forelæsninger over Historiens Philosophie. København: Klein.

Hjelmslev, L. (1959). Essais linguistiques. København: Nordisk Sprog- og Kulturforlag.

Hume, D. (1968). Treatise on Human Nature. Oxford: Clarendon.

Husserl, E. (1965). Logique formelle et logique transcendentale. Paris: Presses Universitaires de France.

Kelly, W. H. \& Kluckhohn, C. (1945). The concept of culture. In: Linton, R. (Red.). The science of man in the world crisis (s. 78-105). New York: Colombia University Press.

Kluckhohn, C. \& Kroeber, L. (1952). Culture: A critical review of concepts and definitions. In: Papers of the Peabody Museum of American Archaeology and Ethnology, 67 (1), Cambridge Massachusetts: Harvard University Press.

Laswell, H. D. (1935). Collective autism as a consequence of culture contact. Zeitschrift für Sozialforschung, 4, Leipzig, s. 232-247.

Leach, E.R. (1961). Rethinking anthropology. London: Athlone Press.

Leibniz, G. W. (1866). Second éclaircissement du système de la communication des substances. In: Janet, P. (Red.). Oeuvres philosophiques (vol.2), Paris: de Lagrange.

Levi-Strauss, C. (1969). The elementary structures of kinship. London: Social science paperback.

Levi-Strauss, C. (1968). Structural Anthropology. Allen Lane, London: Penguin Pres.

Marx, K. (1970-72). Kapitalen: Kritik af den politiske økonomi. København: Rhodos. 
Marx, K. (1974-78). Grundrids til kritik af den politiske økonomi. København: Rhodos.

Merleau-Ponty, M. (1949). La structure du comportement. Paris: Presses Universitaires de France.

Moscovici, S. \& Plon, M. (1966). Les situations-colloques: Observations théoriques et experimentales. Bulletin de psychologie, Paris, s. 701-722.

Panofsky, E. (1920). Der Begriff der Kunstwollens. Zeitschrift für Ästhetik und allgemeine Kunstwissenschaft, 14, s. 321-339.

Pariente, J.-C. (1966). Vers un nouvel esprit linguistique. Critique, april, s. 334-358.

Prieto, L.J. (1966). Principes de noologie, Paris: Mouton.

Radcliffe-Brown, A.R. (1940). On social structure. Journal of the Royal Anthropological Institute of Great Britain and Ireland, 70, s. 1-12.

Ruyer, R. (196). Paradoxes de la conscience et limites de l'automatisme. Paris: A. Michel.

Sartre, J.-P. (1960). Critique de la raison dialectique. Paris: Gallimard.

Sartre, J.-P. (1957). Being and nothingness. London: Methuen.

Sartre, J.-P. (1953). "Réponse à Lefort". Les temps modernes, 89, s. 1571-1629.

Sartre, J.-P. (1943). L'être et le néant. Paris: Gallimard.

de Saussure, F. (1960). Cours de linguistique générale. Paris: Payot.

de Saussure, F. (1959). Course in general linguistics. New York: Philosophical Library.

Touraine, A. (1965). Sociologie de l'action. Paris: Seuil.

Touraine, A. (1966). La raison d'être de la sociologie de l'action. Revue francaise de sociologie, 7, s. 518-527.

Wittgenstein, L. (1963). Philosophical investigations. Oxford: Basil Blackwell.

Wittgenstein, L. (1965). Le cahier bleu et le cahier brun, études préliminaires aux investigations philosophiques. Paris: Gallimard.

Ziff, P. (1960). Semantic analysis. New York: Cornell University Press. 